
SCULPTOR. 



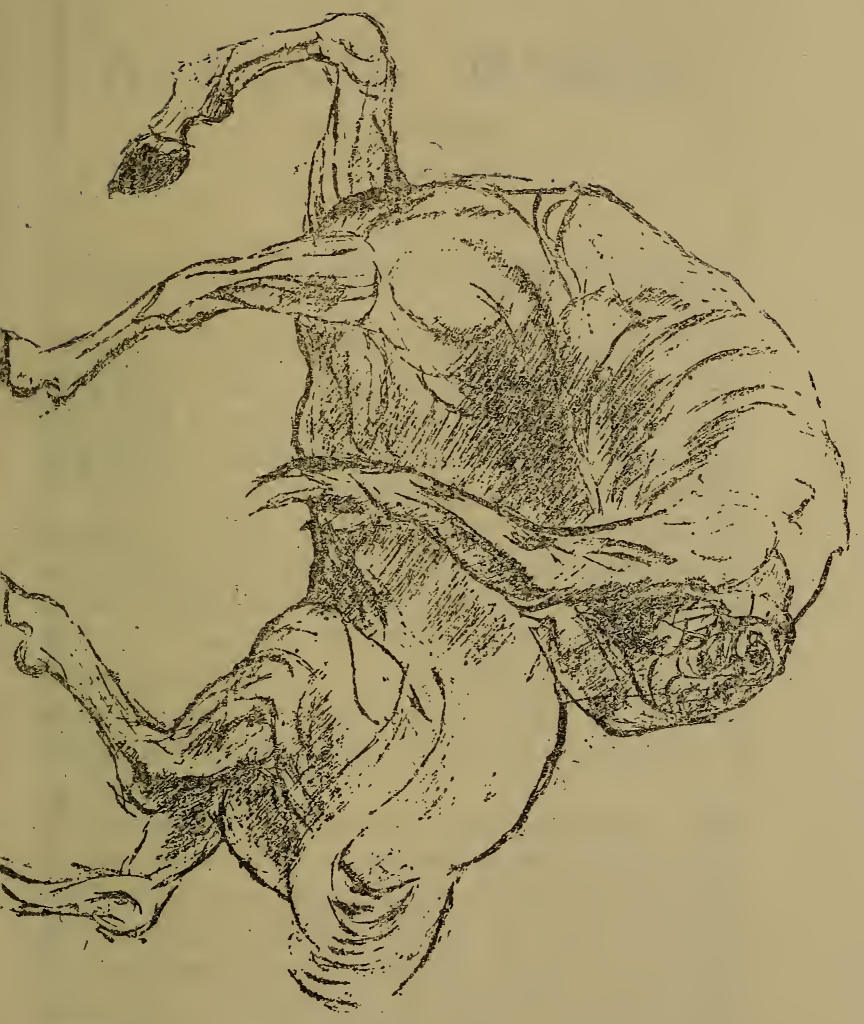





\section{Auguste Rodin,}

SCULPTOR.

I.

WORKS AND THEIR VICISSITUDES.

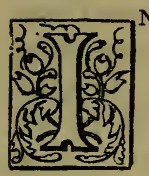

N January 1896, the Exhibition of Fine Arts in Geneva showered flowers on three Frenchmen : Puvis de Chavannes, Rodin and Carrière, that trilogy, almost that trinity, as I have said (1). Sculpture calls forth as many violent attacks as Fresco had raised. Auguste Rodin, hit at as Puvis de Chavannes, had to cultivate that flower of Genius, Patience, so as not to fall under the blows. Like the former he applied himself with energy not to give in, in the slightest degree, and so will have the glory of complete triumph.

Since 1864, one knows of Rodin The Man with the broken nose, Greek mask refused at the "Salon" of the same year, but he revealed himself for the first time thirteen years afterwards at the Salon of the Champs Elysées with l'A ge d'airain (in plaster, also known as The Man of the first ages, 1877). This simple figure, which upsets preconceived notions, is so flesh-like in its reality that the artist is accused of taking casts from nature. "A deep sensation stirred the

(1) Essay on Puvis de Chavannes. 
world of artists" (1). He holds out against the storm, perseveres in a most tenacious resistance, sends back the bronze in its definite form to the Salon of 1880 , where the work so cried out against is finally bought by the State and placed in the Luxembourg Gardens (2) after having received a 3 rd class medal. This was the first battle. Rodin rouses new ones each time he appears, with his thin St. John the Baptist preaching (3) at the Salon of 1881 , with his Creation of Man (4), exhibited the same year. From this moment begins the outcry of common-place criticism, the watchword of the "salonniers." "Go and see the Rodin." "You. have not seen the Rodin?" "Really, now, what do you think of the Rodin?" Then antagonisms take form. The so-much-talked-of studies are published, every one formulates declarations of principles. Henceforth the two camps clash. There are terrible discussions. Cards are exchanged for duels. The timid stammer out, "Rodin is a religion;" the bellicose clamour, "We are Rodinists ;" their adversaries answer, "Let him make us beautiful things."

These he undoubtedly made, and later on others that we will find again partly at the exhibition in the Gallery Georges Petit in 1889 (5). Every one of these masterpieces has

(1) Léon Maillard.

(2) Near the School of Mines and the Boulev. St. Michel.

(3) Modelled in 1879, bronze natural size in Luxembourg Museum.

(4) To be found in Rodin's Boulerard d'Italie studio.

(5) Written in April 1899. 
been the object of repulsive ridicule (1). First for instance, St. Jerome (2), emaciated, stretched out in his desolation. Oh! the poor rag of Humanity (1878). Adam and Eve (1881), two figures first designed for the Gates of the Inferno (3), Eve heavy and massive, with the powerful loins of creative woman, at the same time the mother who trembles huddling herself, afraid yet enraptured to feel within her dolorous womb the throbbing ofa new life (4); a torso of Ugolino (1882), a Bellona with helmet and flowing hair (1883) (5), The Man with the ser. pent (1885) (6), Persée and Gorgone (1887), St. John after decollation, a haggard head, sink into a blood-besmeared dish; The Man walking (1888) (7), Les Femmes damnées and La Miserre (1889) (8). Oh! the withered bodies, flabby, dilapidated, collapsed aged women, mummies still palpitating with snuken in bellies and emptied breasts. Oh! the horror of it! all this that was once beauty-and through the magic of genius has become beautiful once more.... And of the same date a Hecuba

(1) Charles Morice.

(2) Little sketch, Meudon studio.

(3) There is nothing left of Adam, desiroyed and forgotten.

(4) Reappeared at Salon 1899. A bronze full-sized at M. Pellerin's, one reduced size at M. Geoffroy's and other houses, a small marble of it at M. Henri Vever's; another at Auguste Vacquerie's, etc.

(5) Portrait of Madame Rodin.

(6) Belonging to M. Anthony Roux.

(7) One of the Bourgeois de Calais; another was exhibited at the Champ de Mars in 1895.

(8) Bronze belonging to M. Vever. 
crouching, wild, howling, demoniacal; the group of The Dream (1), the Dream of Life (2), and that firm and pensive head with a kind of white cap leaning on the rough block of marble that might be called Thought or Contemplation, whose eyes are full of sweetness and repose (3). Then a Young Mother crouching down near her child who holds out its arms and whose tiny lips seek her breast (1891) (4); The brother and sister, a young girl holding a little boy on her knees (5); a torso of St. John, a Cariatid, a sturdy woman whose muscular shoulder is laden with a stone (6); bas-relief mask Pain (1892), a good piece of work in marble The death of Adonis, whose last breath is drunk in by Venus (1893 and 1894) (7); Galathea (8), The Crest and the Wave, The Resurrection, The Education of Achilles, same dates (9), Orpheus and Eurydice and Psyche and Love (or the Eternal spring), full of all possible grace (1894) (10); Hope (11), Christ and Magdalen, The crouching Man (from the Gates of the Inferno, 1895), Illusion, The Daughter of Icarus (on the same year), that daughter of Icarus

(1) Little bronze, studio of the Rue de l'Université.

(2) Marble belonging to M. Johanny Petel.

(3) Belonging to Madame Durand.

(4) Belonging to $M$. Desmarais.

(5) Studio Rue de l'Université.

(6) Studio, Meudon.

(7) Idem.

(8) Belongs to M. Errazuriz.

(9) Group of three figures in plaster.

(10) These two groups in marble belong to M.Yerkes.

(11) Studio at Meudon. 
whom her vast but failing wings were not able to uphold (1).

Need I refer to the Prodigal son, a kneeling figure whose arms in gesture of despair appeal to the father's kindness? The Rape of a woman by a young man; the Fountain, represented as a sleeping woman offering her graceful body to a satyr who bends over it to quench his thirst (2); the Poet and life (1896), a sort of base of a pillar in which the poet is represented with his head bent forward watching as they come towards him, in a whirl of thoughts and memories, the fiery or voluptuous incarnations of his imaginary encounters (3); and as to the statue known as Lust, have you not, at least when you were twenty years old, with the inner eye of your imagination, have you not seen as is here represented that woman howling, flat on her stomach, with her hands encircling her flashing eyes, whilst towards her there rushes a man whose eager hands seek to clutch her breasts? This young man symbolises Humanity represented as kneeling down before the Eternal Idol (4) who, with her hands behind her back, without defence, meek and pensive, offers him the breast from which he shall drink and the bosom on which he shall sleep? And this Danaïd, prostrate on the

(1) This fine piece of sculpture belongs to M. Cahn.

(2) Belonging to M. Fenaille.

(3) This piece of sculpture also belongs to M. Fenaille.

(4) Belongs to M. Blanc. 
earth (1888) (1), and this Old heaulmiere, a nude figure seated on a rock (2) " an embodiment of regrets and decadence, the picture of a life which has been lived in which all hope has come to naught(3)? $\mathrm{He}$ produced all these beautiful works and then others besides, the history of which 1 now propose to describe as briefly as may be.

Let us begin with the series of busts, which from 1881 up to 1885 and again up to yesterday, he offered to the passionate admiration of an increasing circle. The bust of Jean-Paul Laurens (4) "a tragic mask of which one might say that it had been licked by flames, to such an extent the bronze having the sheen and patten of fire" (5); that of Carrier-Belleuse, with his riotous hair, and then two busts of Victor Hugo (one of which is at the Paris Hôtel de Ville), a Dalou (which we see again in 1889), an Antonin Proust (6), a Henry Becque (1886), a Puvis de Chavannes (1892) (7), a Henri Rochefort (1893) (8). These portraits should be examined : each

(1) Sculpture exhibited at the Champ de Mars Salon in 1890, now at the Luxembourg Museum.

(2) Idem, a small bronze figure.

(3) Quoted from Gustave Gefiroy.

(4) A visit should be paid to the Luxembourg Musenm to see this bust.

(5) G. Denoinville.

(6) At the rooms in the rue Vivienne.

(7) At tha Musée de Picardie at Amiens. A reduction of the profile of this bust ornamented the plrquctte given to the guests at the banquet which was held-in honour of M. Puvis de Chavannes on January 16, 1895.

(8) This bust was again exhibited at the Salon in 1899 together with the artist's Eve. 
detail is a work of art, on which the artist has impressed his thought, the strength of his will, and the form of his particular artistic insight. "Of nearly all these busts it may be said that they in some way remind one of the sculptor's own face" (1). Other busts are those of Bastien Lepage, who died too young, of Legros, the engraver, his friend in London (1882), of Octave Mirbeau (of whom a medallion in 1889 and a marble bust in 1895), of Roger Marx (1889), of Henley, the editor of the Magazine of Art (1892), of Madame Séverine (1893), and of Madame Russel, as Minerva (1896). Then one should admire the bust of Ciesar Franck at the Montparnasse cemetery (1893), and that of Castagnary at the Montmartre cemetery. Again, there are his numerous portraits of women, notably that delightful marble of a woman, showing her adorable bosom, which is one of the glories of the Luxembourg (2). All these busts provoke the same shouts of enthusiastic admiration, and also the same outcries of bourgeois disapproval. The liberal-minded are in ecstasies, but with what disdain do not those who remain faithful to tradition cover these works?" "The bust of Dalou by Rodin," says Ribot," is as beautiful as any work that any artist ever created." Jean Dolent adds with a smile: "What shall I say of the bust of JeanPaul Laurens? It is hideous, it is beautiful, haggard, horrible, sinister; this kind of art is

(1) Daniel Baud-Bory.

(2) Exhibited at the Salon in 1898. 
not appreciated in domestic circles"(1). Much has been said of the bust of Victor Hugo (the first one). It was indeed the likeness of the old poet in his last years, with his forehead, serene and sheer, and his hair which the winds of the sea still seem to toss to and fro. Here one finds again the man and his work. It is the portrait of a genius, handed down to Posterity. The Puvis de Chavannes is admirable, although one finds to blame in this bust too much haughty coldness, the scrupulous reproduction of the well-cut frock-coat on which not a single button is wanting, and the hardness of the look in which one fails to find the kindness of the illustrious painter. The mobile and storm-swept face of Henri Rochefort recalls the pamphleteer, but goes no further, no touch of feeling softens the face of this man, whom, however, his friends proclaim a man of heart. In none of his subjects has Rodin grasped the inner man. It may be that he disdained to do so, and only looked in them for the heroes of the public, and as such carved them in unperishable marble.

In his busts of private persons, one finds more of the flesh, the look, the language and the intention of the subject. In December 1898 appears in the place of honour of the 16th Exhibition of the International Society the bust in bronze of a young American, "An Admirer of Balzac." "From beneath the rigid sheen of the sombre metal look out the individuality of

(1) Amoureux d'art. 
the person pourtrayed, the accent, so to speak, of the Anglo-Saxon face" (1). The most recent of these portraits is that of Alexandre Falguiere, which we shall no doubt see at the next Salon (March, 1899). The worthy Toulouse sculptor is very true to life.

Art such as this, for a long time only wins over to itself the initiated; the profane rush to the assault of these beauties which they cannot understand. They misrepresent these works and, could they do so, would trample under foot those who dare to think differently. The Commissions, the almighty, act likewise. Rodin is fated to learn this truth, every time that he ventures to compete in public. In 1880, in the competition for a group to commemorate the National Defence (to be erected at Courbevoie), he sends in a Vanquished Fatherland, a female figure, who yelling, with outstretched arms and one broken pinion, towers above a dying man. It vibrated with violence, but was found too revolutionary by the jury, who preferred the group sent by Barrias. Rodin did not abandon his conception. He modified it, suppressed the dying soldier, and the statue became the Genius of War (1883) (2). A Committee is formed at Nancy in 1883, under the presidency of the painter Français, for the erection of a statue of Claude Gelée, known as Le Lorrain. Rodin undertakes the work. His Claude is represented erect, leaning slightly

(1) Raymond Bouyer.

(2) One of the reductions belongs to M. Pontremoli. 
forward, with one leg bending under him. His moustache is stiff, his abundant curls float on the breeze, his eyes search out the light which is the joy of life, the gladness of the world. Horses, leaping forth from the shadow of the pedestal, draw after them a radiant youth whose eyes are aflame with sunlight; it is Apollo's car. Exhibited in 1889, this monument, misunderstood, was rejected by the authorities of Nancy. It took three years of struggle and the persistent support of influential friends, before it was at last inaugurated at Nancy in 1892 (at the Pépinière near the Place Stanislas). As to the statue of Bastien-Lepage, for the village of Damvilliers (1889), although its acceptance was not so long delayed it was not a whit the less discussed and criticized. In July 1890, the Commission, known by the name of the Commission of Art Works, rejected Rodin's project for a national monument to Victor Hugo (1). M. Arsène Alexandre has related how the architect of the Panthéon set about judging this design. He had it copied on to a canvas stretched on a frame and had this set up on the spot which was destined for the monument. And the results produced by this absurd proceeding were found a sufficient reason to convict the sculptor of ignorance. Rodin's poet was sent back to him, and there would have been an end of it, but for M. Gustave Larroumet, who after two years' efforts succeeded in getting the commission for $\mathbf{M}$. Rodin.

(1) First model in 1886. 
This Victor Hugo for the Panthéon, "rescued " by M. Larroumet, only awaits to be executed in marble. Similar in part to the Victor Hugo which is shortly to be executed in the Luxembourg gardens, the poet is represented as listening to the music of the waves, seated on the rocks which are shaken by the sea; with arms stretched out towards the shores of France, he repeats to the wind which tosses the waters to and fro his lyric dreams. Three syrens, supple of back, long of tail, look up at him. An Iris, messenger of the gods, points out the future to him. In the monument for the Luxembourg (1), Hugo is seated in the same way. The Muse of Tragedy whispers counsel in his ear, whilst behind him stands erect a form, with emotion depicted on its face, which represents his inner voice (2). These women who address him, dripping with sea-weed, pour into his ears their passion and their legends. Under their inspiration he wrote more than one immortal tragedy and in the evening of his life breathed in the glorious peace which they had given him. It is thus that Auguste Rodin imagined the rugged artisan of human thought, powerful and tender, it is thus that he has pour-

(1) Salon du Champ de Mars, 1897.

(2) A plaster cast of this "Inner Voice" had been offered to the Nalional Museum of Stockholm by Rodin, after the Exhibition in that City. The Nouseum Comniittee refused the statue. The King of Norway and Sweden, indignant at this piece of rudeness, made pressing advances to the sculptor, apologized and offered him a decoration and asked for the "Inner voice" for his private gallery. 
trayed him, and it is as such that we shall admire him.

An offer is made to Rodin to join the Committee for the decoration of the Paris TownHall, but nobody thinks of asking him to contribute in any way to this decoration. He then continues his mighty labours. He erects on the square in Calais, in June 1895, that group representing the six citizens who saved the town, for which a subscription has been made, and here again he had to suffer all the horrors of officious annoyance. History has handed down to us the story of the heroism of Eustache (of St. Pierre) and of his chance-companions, Jacques and Pierre (of Wissant), Gauthier (of Vismes), Andrieux (of Ardres), and Jean (of Aire), who went barefooted, clad only in their shirts and with halters round their necks, to the camp of the King of England, Edward III. It is a memorable page in the hislory of the XIVth century. It belonged to the intrepid sculptor to consecrate it. The first, whose arms are linked together in the heavy key which he is about to hand over to the mercy of the conqueror, looks proudly before him, haughty in his self-sacrifice. The second clasps his head with a gesture of despair ; a third, sorrowful and downcast, thinks of those whom he has left behind. Two more, again, wave to each other mutual encouragement. Such is the fate of the vanquished (1).

(1) A model of this was exhibited at Georges Petit's Gallery. The work was finished in $\mathbf{1 8 9 2 .}$ 
Never before had a pedestal supported men clad only in their shirts. What provincial abomination! The Burghers of Calais might certainly have put on their breeches and their caps to go to execution. Rodin had not thought of this. He was reminded of it.

He drew himself back into his solitude and thought, giving little heed to the mob which was howling around him, the far-off echoes of whose cries but barely reached his rudimentary cell. Day after day, swallowed up in that world in which the living never cease to pray for the dead, hour after hour he adds to those Gates of Inferno which M. Edmond Turquet, then Director of Fine Arts, commissioned him to execute for the Trocadero Museum of Decorative Arts (1). On this arch, which is more than eighteen feet in height,with its framework and its head-piece, on these two panels which stand back a poetic yet a terrible spectacle unfolds itself. Inspired by Plato, by Plutarch, by Virgil, by St. John and by Dante, whom he has placed there as the all-powerful creator of all this magic, he has grouped together in various groups more than two hundred figures, marvellously modelled, which in some degree may be held to represent Humanity on the march through the horde of its passions. His imagination has fashioned forth that rustling of the dead, which Homer compares to the flight of frightened birds. This conception came to him as far back as 1875 . On the upper

(1) In 1880, at the time when the Age of Bronze was purchased by the Government. 
triforium in front of the drum, there is a naked man crouching down, with bowed shoulders and heavy arms, which need to be strong to support his rnassy head. This is the Thinker, who dominates the colossal work. He re. minds one, by his attitude and his expression, -by the very form - of the expressive Penseroso which Michel-Angelo placed in the church of St. Lawrence in Florence, on the tomb of the wretched Duke d'Urbino, Lawrence de Medicis, the father of our Catherine de Medicis, at whose feet he next placed a Twilight and a Dawn.... Higher still at the top of the tragic door three souls of the damned bend down and clamour over the abyss, "All ye who enter, abandon hope." All ye who are born into the world, abandon hope. Ye who have faith, who have love in your hearts, who have the illusion of happy morrows, who proclaim the eternal triumph of art, who follow the sun in its course, who live only for nature and for humanity, all ye must abandon hope.

Rodin, however, resists and patiently continues. Each day brings with it its anecdote. After the Exhibition at Geneva in 1896 he offers to the hospitable town several of the works which had figured there, and amongst these an admirable Crouching Woman in bronze. This statue is found a year later, forgotten, in the cellars of the Museum shrouded in cobwebs. "These are trifling facts which history will not overlook" (1).

(1) Mathias Morhardt. 
The Société des Gens de Lettres having collected the money to raise a statue to Honoré de Balzac apply to Rodin (1), agreeing from the outset to give him full liberty in his treatment of the great man. Intimidated, at first he hesitates, and then accepts, and during ten years seeks to render, living to our eyes, that writer of whom Lamartine said, "There was about his exterior as little polish as about his genius, his face was the face of an element." This statue was to undergo the most extraordinary adventures. Admired, ridiculed, refused by its owners, paid for by subscription, purchased by an amateur, and in the end returning in to the posession of its creator who, although he is a poor man, refused his generous offers, there was a better battle fought round it than round a flag. It was spoken of as a "shapeless block;" these were friends of Rodin who admitted that it was a "serious mistake ;" one heard the story of the President of the Republic who, during a visit on the official varnishing day, had an amiable word to say about every work, but did not condescend to honour with even a glance this wretched great writer, etc. Everybody has something to say about it, either in approval or disapproval. People of sound sense do not hesitate to express their opinion upon it. M. Harpignies says : "I do not criticize it, I do not understand it." The poet Léon Dierx is still more severe. "This is

(1) The Sociéte had it appears applied first to another artist, who died without carrying out the order. 
a nameless practical joke, which by the way has been going on for the past ten years." And M.Alphonse Humbert adds, "This is what has been made of a man who certainly had talent" (1). But, says another, "Look at it for a moment, look at this floury block as the quizzes call it, portion it out in your eye into silhouettes, and you will find in it the swaying of a heary man, the harmony of a ponderons frame, all in perfect truth, for Balzac was a big man with heavy limbs" (2).

One would have thought that it befited the Société des Gens de Lettres to act in the matter the most reserved way. The Committee however decided on a different line of conduct. They were under the obligation-by the terms of their agreement-to accept the model, but one does in vain assail the self-respect of an artist from whom one has little to fear in the way of litigation. A member of the Commission "defied the Municipal Council to grant a site in Paris for the erection of this monstrosity." Then the Committee put the question to the vote, and informed M. Rodin that by eleven votes against four, they were unable "to recognize Balzac" in this sketch. After this expression of opinion, Auguste Rodin, quite placid, wrote to the newspapers as follows : "Desirous above all to maintain my dignity as an artist, I beg you to make public that I am taking my statue away from the Champ de Mars, and that it will be erected nowhere."

(1) M. Léon Bailby in La Presse.

(2) M. Louis Richard in Alceste. 
Would the City fathers of Paris have been as ferocious as was suggested? M. Levraud (1), president of the Committee of Fine Arts, who often took the lead in artistic matters at the Hôtel de Ville, admitted: "I am certain that a great artist like Rodin had a great thing in his mind." There were contrary opinions, not very decisively expressed. Messrs. Bellan and Rebeillard "reserved" their opinion. "However great may be my admiration for Rodin's great talent, it is my opinion that this time the artist has made an absolute mistake," said M. Lampué. M. Grébauval went still further and said "it would be ridiculous to give a welcome to this lump of stuff," and M. Labusquière energetically declared that "if a refuge was required for the statue it was from and not for it."

Be that as it may, Rodin had an admirable awakening. All that is young in literature rose up to affirm its sympathy with him who had succumbed in this novel kind of encounter. To the men of letters added themselves a certain number of painters and sculptors. And the circular in protest against the treatment of M. Rodin came back covered with signatures. "The friends and admirers of Rodin... encourage with all their sympathy the artist to carry out his work to the end, without paying any heed to present existing circumstances and express the hope that in a noble and refined country like France, he will not cease to receive

(1) Now deputy for Paris. 
from the public the consideration and respect to which he is so fully entitled by his lofty probity and his admirable career." A subscription was opened for the purchase of the Balzac and amount was obtained in a short time... But an enlightened amateur (1) had by that time bought the statue for himself, and this put an end to this generous contest (2).

At the same Salon (1898), Rodin exhibited those two lovers embracing each other, who mingle their breath, the woman surrendering herself on her master's knees. "a tender and strong couple which passionately stands forth from the silent rock" (3); that Kiss which forced the admiration of one and all, by reason of the way in which the tender and trembling light which was poured upon it, made of the marble real passion-swayed flesh and blood, " an ideal piece of sculpture" (4), which had already been seen twelve years before (5). The dealer:, less contemptuous, agreed that this was a man who had to be taken into account. At Barbedienne's and at Thiébaut's one can see reproductions of The Kiss, of Adonis, of The Sculptor and the Muse, of Spring, in which a sturdy shepherd embraces a supple girl who offers herself to his caresses. Beyond the seas he is glorified, he is sought after. A recent

(1) M. Pellerin.

(2) The Balzac is now at the Meudon studio.

(3) Raymond Bouyer.

(4) Léon Maillard.

(5) Marble belonging to M. Antony Roux. 
incident, of a warlike nature (1) destroyed in its conception the Gladstone which the partisans of the old statesman had asked Rodin to execute for one of the London squares. The jingoes rose up against this and the order had to be given to an English sculptor. But it is not of recent date that Rodin is admired in far-off lands. Ghili ordered two monuments of him (in 1883 and in 1884). The sketches of these monuments, which were never paid for, were lost during the revolutions in that country (2). One remembers that equestrian statue of General Lynch, represented bareheaded and with his arm stretched out in a somewhat classical style, and that President Vicunha, erect and proud, the pedestal of which statue, ornamented with historical bas-reliefs, supported a female figure lifting her grateful eyes towards him.

At present, he is finishing a President Sarmiento (1898) for the Argentine Republic. From the pedestal of unhewn stone on which this Liberator stands aloft there rises an Apollo, who with a superb gesture brushes aside the thorny growths. Serpents are writhing at his feet. Disdainful, he looks towards the dawn of Liberty, still only half emerged from the marble, he is radiant with strength and spirit.

Thus "there will nothing have been wanting to the genius of Rodin," says M. Octave Mirbeau, "not even the painful and perhaps invi-

(1) Fachoda, November 1898.

(2) These sketches, a third of life-size, were highly finished. M. Rodin possesses photographs of them. 
gorating honour of having been contested by the mediocre and persecuted by the hatred of fools." The ardent southern sun will inflame with burning kisses this block of stone, roused into life, and the citizens of the Argentine will contemplate it with pride under the vast heavens of their city.

\section{II.}

\section{RODIN AS A DRAUGHTSMAN.}

The sculptor has revealed the treasures of his portfolios, filled with drawings such as the elements produce. "He expresses this world of movements by the gesture, the attitude, the rythmic and decisive movement of the exterior forms which he discovers and sets down " (1). Marvellous and dazzling is the work which was to be seen at the exhibitions of the Pastellists and Painters and Engravers and elsewhere. The profiles are tender and robust, virile in their grace. In no case do the lines lack in strength : a dash, a dot, a nail-stroke, all tend towards rendering the expression. "This quality, difficult to explain, which he possesses entirely, is to be found in the best Greek and Egyptian artists " (2). And yet not one amongst them came more close to life than he does.

(1) André Fontainas.

(2) Ob. Quentin in the Art Juurnal for November, 1898. 
He studied painting at the studio of Lecocq de Boisbaudran - there have been seen pictures which he painted when he was a very young man and when he used to be the comrade of Legros, the engraver, who has now settled in London-making copies in the Museums. He made some furtive experiments in landscapepainting and he painted the portrait of his father. His draughtsmanship is not, however, the application of the theories of any school, still less is it a regular process. An idea haunts him. He snatches up a pencil-stump, tears a leaf from his pocket-book or uses the back of a prospectus, and rapidly fixes and embodies this idea. The fleshy curves dart forth, draw back and join together the muscles which entwine and coil like serpents. In these sketches there is as much of plastic art as of science of draughtsmanship. "The drawing heralds the sculptor's work and comments upon it" (1). One might fancy the subjects modelled in clay by the slow and firm thumb of the sculptor, such is the harmony with which the lights and shades play upon these supple forms. A hastily-drawn face completes the body. It was only the movement which had tempted the draughtsman.

Various art journals have published, on the occasion of the annual Salons, sketches by Rodin, representing the works which he was exhibiting. Many of these sketches are still remembered. The Man and the Bull, Prome-

(1) Roger Marx. 
theus and the Oceanides. It was a revelation. Since then he has exhibited dry-points. V. Hugo, Henry Becque, Antonin Proust; an innumerable series of portraits and frontispieces for the books of friends have been seen. $\mathrm{He}$ illustrated Emile Bergerat's poem Enguerrande (1), gave a prelude to Octave Mirbeau's Jardin des Supplices, and made a number of illustrations for a forthcoming edition de luxe of this book. These drawings have been admirably traced from Rodin's original by M. Clot. One hears of a copy of the Fleurs du Mal, unique and above price, illustrated by him throughout (2).

The vigour of his lines is incredibly great; there is no falling-off anywhere; there is confusion nowhere. At times he makes his models assume extraordinary poses for the purpose of making some notes, intantaneous sketches, of recording certain aspects from which to instruct himself. He has thus in his possession hundreds of amorous women with writhing backs, with legs stretched-out or gathered-up, with fat bellies and broad rumps. Some are stretched out like grass after a storm, with loose breasts, their head pillowed on their arms; others crouching down, on their knees, or prostrate offer to the eye the most suggestive fore-shortenings of the female form; others again, their flanks encircled with desire, bend back, offering their lips, ready for the embrace,

(1) Frinzine et Klein, publishers, 1884.

(2) Belongs to M. Paul Gallimard. 
and one can see the blood which fills this flesh and that "spirit of existence which resides in the innermost vault of the heart," as in the Vita Nuova, the lover of the symbolical Beatrice sings.

Art is simple as Life is, and as Life Art is complex. The least of masterpieces, engendered, one might fancy, by a ray of sunlight, are the outcome of scattered sensations. A faithful copy from Nature does not suffice. And it is thus that Rodin, with his passion for expressive forms, was obliged to gather here and there and everywhere all the details, to note them down and to bind them together. "I am too literary... I do not make enough sketches in the street," are the words which in Amoureux d'Art Jean Dolent puts into his mouth. It should be observed, however, that he has collected not a few. And - in these rough, hasty, unfinished sketches, which at the same time are vigorous and synthetical, in these tangles of linıs here shaded with a patch of ink, here lighted with a dash of white, Rodin has untied the knot of his conceptions. The eye notes in these drawings each separate movement or impulse, follows the framework of the bones, pries into the anatomy of the forms, and loses itself at leisure in the midst of all this wealth looted at hap-hazard by the artist's intuition.

Rodin disdains not one line. "His is a marvellous temperament, born for the acute observation of human reality "-is the explanation given by M. Louis Gonse in his History 
of French Sculpture in the 19th century. But one would look in vain here for the frivolous or graceful silhouettes of modernism. For these Rodin has no eyes. They do not enter into his daily imaginings; they do not pass along the path he treads.

Touching but slightly those secular and heroic epochs of which the poets have made the gigantic sepulchres of their thought, he has seized in them the eternal side and their particularity. Have you examined the dry point which adorns the front of the second series of Gustave Geoffroy's Vie Artistique? There are three women in despair under the Tree of Sin, whose strong and graceful nudities tremble in the fever of tears, whose eyes, according to Alighieri's expression, have become the very Desire of IVeeping. There are also those figures of the second canticle of the Florentine Commedia, the Purgatory. Have you turned over the leaves of the enormous albums of 142 sketches, collected from 1880 to 1885 , executed in heliogravure by Manzi and published by the firm of Goupil at the instance of that courageous amateur whose name is M. Fenaille, Drawings by Auguste Rodin? These are those hasty pages of which I spoke further back, in which the liquid lines, the splashes of ink and the graduations of colour are harmonized with science. These drawings for the most part refer to the groups of figures on the Gates of the Inferno, to which he has devoted thirty years, that inferno which Plato refused to describe. One sees Dante on his way; one meets dead men 
clamouring for a second death, those who stagger under a hood of lead, Ugolino, whose hunger grows as he tries to still it, resuming his horrible repast, Mahomet with his entrails hanging out and his heart beating in the open gash of his ehest; gluttons and those sated with lust plunged in à slough of mire "which seemed to come from the jakes of mankind," the damned swelling out the boiling pitch, Farinata degli Uberti, the conqueror of MonteAperto in his robe of flames, the trees whose fruits are poisonous thorns, and those birds who, perched in the bloody grove, cry out with human voices: "Pity! Pity!" and all the visions of the Bollandists and all the tragic beasts of Dante's forest.

\section{III.}

\section{GHARAGTER AND PLANS.}

At the top of a hill in Meudon, perched above a chaotic landscape, all bloated in the mushroom-farms, the house of Auguste Rodin stands out against a screen of forest-trees. This is the "Villa des Brillants." At its feet is a valley, through which the Seine creeps lazily, a valley into which the eye plunges and finds pearls of beauty. The people round about have given it the name of "The Flowery Vale." Its colour is intense, now joyful, now sad. The clamour of factories has not yet drowned the solitary song of the abyss, and the slowly-rising smoke 
which coils like a turban in front of the hills has in its wreaths many a mirage. In the distance is the bridge of Sères, sturdy and humpbacked. Opposite are the terraces of Bellevue. Trees, gardens and cottages stand up above and overpower the factories which here and there are springing up. The mind floats above it all. Here one is high up in the clouds.

The house offers cordially its hospitable shelter, its rooms filled with antique joys and modern pleasures. Side by side with Roman, Greek, or Egyptian rarities, birds, flowers, fragile statuettes, here is a portrait of the master by Sargent, another by Avidgo:, a third by Jean-Paul Laurens (1). Here are paintings by Carrière, luminous flesh-pieces, faces alight with expression, paintings by Claude Monet, by Degas, by Pissaro, vibrating engravings by Bracquemond and a thousand things of which one never tires. The robust torsos created by Rodin here clash together and repel each other. In one corner Honoré de Balzac bends his mighty head. And little groups, translucent marble, radiant with force and beauty, mingle their limbs will all this picturesque disorder. Daring subjects, supple bodies, muscles straining with life. Triumphant girls, prostrated youths, frenzied embraces. Love, Lust, Desire, Cruelty. A Temptation, in which a waked woman throws herself, joyous and full of desire, on the back of a hermit who has fallen on his face.

(1) From the fresco at the Panthéon. 
A female faun who embraces a young man, and so embraces him with эrms and legs, which coil around him like snakes, that one sees how soon he will loosen his hold upon the rock which he clasps, how soon he will fall. Lovers sated with love; others who seek each other's arms once more : "Come to my heart," she says, "it is not only in my eyes that there is Paradise." An Adonis A wakened by the Muses, that Adonis, the feminine spring of the weary religions of which Venus is the virile sun. Limpid stones, a Venus bending over the Adonis whom with a kiss she is about to turn into a flower. Elsewhere a "Man Contemplating his Work; a powerful torso, the head of this body bent forward, which is called La Méditation; Youth and Love, Summer, Spring, Three Graces, represented as dancing (1896) and others besides.

Rodin has isolated himself so as to keep his will intact. For many years he lived in an old house in Sèvres, before going to this cottage at Meudon, above the Flowery Vale. It is there that he lives, together with the lady who is the devoted companion of his days. Let us watch him at work, be it in this remote corner of the Boulevard d'Italie, at the Clos Payen, where at times he shuts himself up entirely alone, in that last-century hermitage which turns its back upon the street "buried under the trees and in the grass, near the Bièvre" (1), in silence, far from the roar of Paris, far from the inquisitive,

(1) Léon Mailląrd, 
the environs, and the evil-tongued, or be it in one of those half-mysterious retreats in the suburbs, in which he delights, in the Boulevard de Vaugirard, or in the Faubourg St-Jacques, deserts which he peoples with his dreams, or be it again in that vast stone house where the State keeps its marbles, where the artist, now for some twelwe years, has evoked a whole world of pure beauties.

Near to the busy quarter of the Exhibitions, this enclosure spreads out like an oasis in the tumultuous city. The immense courts strewn with patches of chalky white, with blocks of stone lying in the grass, with fragments of statuary or of architectured stones, have a delightful horizon. Lofty trees, alive with birds, grow yellow in the winds of autumn, casting their last leaves, as with a tragic gesture, to the neighbouring masterpieces. The air of Mantua, of Florence also breathes through this quiet spot. IVide doors break in upon the walls, the doors of the studios which the State generously puts at the disposal of some artists, where names are summarily indicated by initial letters.

$M$ stands for Guillaume; $G$ for Jean-Paul Laurens; $K$ for Frémiet; $J$ for Rodin. The artists change quarters occasionally. Rodin was formerly in the $M$ studio. Now the $H$ studio has been granted to him for the manipulation of his blocks of marble. It is at the $H$ studio that his assistants are now busy with their chisels on the Victor Hugo for the Luxembourg. The rooms are square, white 
washed, the floors impregnated with bitumen, where not one detail can lead the artist's thoughts astray-cold but glorious. A little glimpse of nature is the joy of their austerity and those who inhabit them garnish them with their genius.

Let us knock at Rodin's door. Here he is, entire in his splendour. The most indifferent strangers come to see him and to listen to him. "It is a rare pleasure to hear him speak about art, about his own work and the work of others"(1). Let us enter into this "vast monk's cell filled throughout with the man's mind" and this cell from which will come forth "statues as beautiful as flowers" 12 '. The man approaches us, hesitating and timid. His clothes are soiled with plaster. A medal by Ringel depicts him, with his bristling hair. his flowing beard and his ingenuous but positive eyes. The forehead is powerful, the nose inquisitorial, the lower part of the face is swathed in the heavy beard, over one of " these powerful necks which Balzac loved, which unite more closely the heart and the brain" (3). Things surprise him as they might a child. His bust is rather heavy, as indeed it is portrayed by Mlle. Claudel-sturdy and reposeful; his gestures are full of force. Examining you, without your knowing it, he takes notes and, prolonging his silent contemplation, listens to you readily without

(1) Ch. Quentin in the Art Journal.

(2) Fagus, Trois Cours d'hommes.

(3) Daniel Baud-Bovy. 
hearing what you say. There are deep abysses in his eyes. This is evidently not a man who is in the struggle for life-life which he loves in whatever way it may manifest itself, for as he asserts " Everything in Nature is beautiful, because it is alive," and again "Beauty is Life whatever form it may take."

Can matter be impregnated with the breath of life? Such was his creed and that is why he has never ceased to seek and to produce. He had few masters, friends rather: a sculptor, Carrier-Belleuse (from 1866 to 1870)-his connection with Barye in the basement of the $\mathrm{Mu}$ seum was of the shortest duration-and two painters, Puvis de Chavannes and Jean-Paul Laurens. Attributed to him as pupils are Bourdelle, who represents the violent grin, and Mlle. Glaudel, who is so strong and so sweet. This lady spent five years under him. "I showed her where she could find gold, but the gold which she finds is truly her own." She made a fine bust of him, and an etching for Léon Maillard's book. " It is Rodin himself," wrote M. Morhardt (1), "Rodin at work, surrounded by his groups and his statues, Rodin stiffening his loins, bending forward. plunging, drawing himself up, holding out at arm's length a lump of clay, or bending back to the extreme limit so as better to judge a profile above his head."

Fame has brought with it neither fortune, nor peace. I have described his never-ending struggles, his constantly renewed disappoint-

(1) In his article on Mlle. Claudel, Mercure de France. 
ments. Born in Paris, in 1840, up to the age of thirty years he was forced to do drudge's work. He collaborated from 1871 to 1877 on the caryatides at the Bourse in Brussels with Van Rasbourg, the Belgian, and during that same year executed some decorative work at the Trocadéro palace. Then, hazarding himself into the Sèvres manufactory, he tried his rough chisel on fragile surfaces, on the crumbling potter's clay. His delicate figurines can be seen at the Luxembourg Museum, in pate d'application on a decorated vase, attributes and Bacchanals, and at the Sèvres Museum a decorative allegory called Winter.

His right to live and to speak was won by him under the stress of need. The ever-recurring attacks upon him have but made him better in the fight. His talent taught him to find an unknown power in life, all the science of detail in a sobriety of lines which owe nothing to anything but Nature, and the most independent amongst artists have trembled under his influence, as will be seen in Salons to come. Since then his ambition has limited itself to the production of what is noble and true.

To the bronze gate on which he unfolds the immortal scenes of Dante's poem (1), he wished to add a second arch, to be called Eeath and Resurrection. But of all his plans the one which he most wishes to carry out is his Pillar

(1) Ordered in 1880 by M. Turquet for the Museum of Decorative Arts. 
of Work, the monument, the realisation of which was so ardently desired by M. Armand Dayot.

Work is the true glorification of mankind. Without it nothing is possible, or lasting, or vital. God's Words, ": Thou shalt earn thy bread by the sweat of thy brow " mean simply, "Go, and exist." Around the spiral of this daring pillar workmen would be represented as climbing heavenwards in the form of synthetical reliefs. An open work staircase would render them visible to our eyes. The part below the ground would show the horrors of the mine and of the pit, whilst in the light of day would be seen the crafts of the workshop and the open-air. Each storey, rising higher in cerebrality, would show the more intellectual professions. It would show the uprvard tread of Society in its essential aspect. At the very top, two winged figures, the blessings of Work, would stand above the abyss.

At the foot of this all-embracing staircase two colossal figures, Day and Night, watch, as they pass before them, the workers of the pick, the pen or of the paint-brush, of the chisel or of the word (1898). "All the figures in this rnonument, except the symbolical fizures of Day and of Night, and of the two Blessings" writes M. Gabriel Mourey, "would be dressed in modern costumes."

The bust of Puvis de Chavannes by Rodin has been given to the Amiens Museum. Whatever may be the claims of this city to the possession of the statue of the artist who did so 
much to glorify it, why did not Lyons assert its right and secure this work of art for its collection of men of Lyons worthy to be remembered? The day must soon come when the author of Le Bois sacré will have to figure in this collection, side by side with Hippolyte Flandrin and Meissonier. Of whom better than Rodin could Lyons order a bust? Monuments will everywhere be springing up in memory of the illustrious painters, the painter from the banks of the Seine, the painter from the banks of the Rhone, and what more conscientious friend-when all is said and donecould be found than Rodin? The author of the Balzac ought to execute the Puvis de L'havannes. What am I saying! The bust has already been executed. One has only to ask for it.

He must also finish that Beaudelaire, the poet of revolt, of wine and of death. A Committee for the erection of this statue, which was formed by Deschamps at the offices of $L a$ Plume, under the auspices of Stéphane Mallarmé and the presidency of Leconte de Lisle, published a book, about 1896 to which all the young writers of the day contributed Rodin has in his possession at Meudon a bust of which he could make use. Inspired at one and the same time by the numerous portraits of that " poet whose deep heart was peopled by Gods" (1), " that cruel alchemist" (2), " haunted by

(0) Léon Dierx.

(0) Edmond Picard. 
vice and terror, by love and prayer " (1), the portrait by Bracquemond (1861), the five portraits in Asselineau's book, including the one by Courbet (1848) and the two by Manet (1862 and 1865), the one by Deroy, hairy and bearded (1844), described by Th. de Banville in his Nouveaux Camees Parisiens (2), the one by Alcide Sauvaire after the photograph taken by Nadar, inspired also by the medallion painted by Alexandre Lafond which figured from 1861 to 1863 in the shop of Poulet-Malassis, the publisher, as by the heads drawn in black pencil and finished off in red crayon by Baudelaire himself, Rodin has called back to life for our eyes that poignant smile and that life of torture. To achieve this he was forced-and these are his own words - to abandon that sort of photography which till now has been employed in sculpture. There will be here another portrait for immortality.

\section{IV.}

\section{COMMENTS.}

Rodin knew how to violate the Truth. This will be his claim to the gratitude of the arts. He has walked straight before him, calling not

(1) Emile Verhaeren

(2) Was formerly in Asselineau's possession and since then in the hands of Dr. Piogey. 
for help, indifferent to clamour and to the beating of cymbals in his honour. He is not one of those who are mad with vanity, such as art, since his days, has numbered a few. He acts without calculation, for such is his temperament. Hehas contemplated, he has understood, he has conceived living persons whom his taste for correctness of detail has rendered still more rea!. And out of his brain his work has issued forth in full armour. Here we have MichepAngelo with four centuries of misery superadded.

Since "amidst the works of sculptors those only stand out where art has made herself the interpreter of mind and of beauty" (1). Rodin's works will be a cluster on the forehead of the age. The furrow made by this daring ploughman is impressive in its tracing. Here is no wavening, no falling-in anywhere. "He has received the reward due to his patient research... life has revealed herself to him " (2).

Far from the effeteness of an insipid humanity - the disgrace of those who follow the beaten track-love is not the unctuous pomatum of selfpampered senses. It is the almost bestial embrace which makes the muscles start out, which tortures and exhausts the glutted lover, it is Desire launched on the Ocean where there is no rest from human suffering. Come and admire in these creative unions, in these cutwind muscles, the fervour and the cultus of form, contemplate these beautiful young bodies, these

(1) Roger Marx.

(2) Mathias Morhardt. 
adorable bosoms, these loins and these thighs, these quivering flanks, these nervous and graceful arms, these treasures of which Baudelaire sang in the line :

And her belly and ber breasts, those grapes on my vine!

Amidst the pieces of work which have already been completed and are now scattered abroad or in those in preparation, contemplate all these lovers, all these frenzied women, these mouths in unison, all this flesh in labour. It is Power in Passion. "Terrible and formidable, tearing the convulsed flesh under the whip of lust and the bites of temptation, he is tender also and he is chaste and none more than he has endowed the body of woman with more radiancy of grace, more youth and more caress!" (1).

The mind, strangely moved, starts at the sight of this display of fiery passion. Husband and wife examine these embraces which they ignore, these kisses which bite, these caresses which break the limbs. The flanks of the ingenuous girl who passes palpitats and her bosom rises up and yet she sighs and goes upon her way, for " Rodin is the sculptor of sorrowful Lust" (2) and the nubile girl is affrighted by this love whose pleasures seem to be sufferings.

"From being conventional, sculpture has become expressive. For the last twenty years, since Rodin came, it has been going through a

(1) Octave Mirbeau.

(2) Gustare Geffroy. 
Shakespearian Revolution"(1). It amplifies itself till it touches the limit to which the artist's imagination carries him in the treatment of the subject which he has to produce. Certain faces are only seen at a certain angle and this precludes the possibility of copying them too faithfully. Can you conceive Napoleon in his slippers reading the newspaper? And so there are men who can only be represented on horseback just as there are vulgar acts in life which glitter with poetical majesty. It is thus that this educator "who does honour to his age by an unequalled probity" (2) understands art in life. "The divine masters of Greek sculpture would have greeted as one of themselves this artist who so delights in living and sensuous lines" (3). Like them, he combines vigour of the form, a sincere delicacy and what is true to Nature. There is in his merest fragments an expressive and entire force. Rodin is a worker in clay who can be compared to the best poet. "Force, truth, tenderness, are not they the highest life, the supreme expression of genius?" (4). " Rodin! Rodin's work, it is Thought on heat" (5).

To tell the truth, one ought to recall all the van of criticism during the last ten years, the clear stories of Gustave Geffroy, Roger Marx's pages full of feeling, the studies of Gabriel Mourey, of Daniel Baud Bovy, of Octave Mir-

(1) Raymond Bouyer.

(2) Léon Maillard.

(3) Ch. Morice.

(4) Charles Quentin.

(5) Jean Dolent. 
beau, Fagus's sincere enthousiasms, the views and notes of Raymond Bouyer, of Charles Morice, of Georges Denoinville, of Morhardt, of Mauclair, of André Fontainas, of Jean Dolent, and of Louis Richard; one ought to read that volume by Léon Maillard from which I have quoted many passages, to refer back to the book which Brouwnell published in America, about 1888, to the articles in The Studio, in The Art Journal and in all the French and foreign reviews. But "there are subjects of which it may be said that when all have pronounced their opinion on it, and each individual has said all that he has to say, there still remains all to be said about it" (1).

What tempests as each new work has come out! What insults, and also what adorations, unwearying, never to be turned aside! The man in the street too long satisfied with starched sculpture, at last understands that all this is for him. Does not Rodin work for the masses, for the marble, for the years to come? Persuaded thatitis aboveall art which forms the education of the multitude, persuaded also that all that we now see in Paris will not last and that the limbs of the statues will fall down after the crumbling cornices, he has defied the inclemency of the skies with the materials which he uses. The forms of his groups are enclosed in geometrical figures, where each holds the other fast and where all balance and maintain each other. So much for their lasting power.

(1) Fagus, 
To appeal to the mind of the people he has exaggerated the "force" of his subjects, in proportion to the number of those who are admitted to contemplate them, endowing them in addition with a certain somewhat heroic side, which no exact copy could possess. He remembers Aristotle's immortal phrase: "Poetry is truer than History."

Fatally, the sin of Adam controls his effort, because it dominates our race and constitutes its mysterious origin. Sensual, it is true. No pagan mythology ever had " that diligent and enthusiastic adoration of matter, always moving and always changing " 11 . One must always applaud it. Everywhere one finds the glory of the Venus of Milo. As in this magnificent and chaste torso, its beauty is always true to life, because in it divinity blends itself with humanity.

But what man was understood from the very outset? Certainly it was not Rodin. If an enthusiast calls him " the most powerful sculptor whom France has known since Houdon and Rude," and speaks of his Balzac as prodigious (2), if Geffroy tells him in his dedication of the second series of his Vie Artistique: "You have proclaimed, in new accents, the depth of human feelings; the sorrow and the joy of love, the grandeur of intelligence, the unending, unrespited beauty of life," and adds, about the Gates of Inferno, "it is like a profound book... this pro-

(1) André Fontainas.

(2) Camille de Sainte-Croix, 
digious repertory," if Denoinville has described him as "filled with the great love of humanity and an anxious desire for truth" if Maillard, speaking of that statue which was so much discussed, cries out, "The power of evocation is here complete... It is the Balzac of $i a$ Comédie Humaine!" if Mauclair affirms that it is " a votive stone offered by one genius to another," there are others close at hand who find the same statue " shapeless, out of balance, without life," adding as regards the artist, " the poor man. Need one recall his disasters, the Burghers of Calais, the Gates of Inferno. the monument of Victor Hugo" (1), who pity him mildly as where one says : "M. Rodin's Kiss displays all the artist's genial qualities and relieves us of the necessity of speaking of his Balzac, which will add nothing to his glory" (2), or else deride him ironically. "Because he has produced the ridiculous piece of work now on exhibition in the Machine Gallery, Rodin is a genius!" (3) “Paris, and let us not regret it too much," retorts M. Arsène Alexandre, " is filled with things which were formerly considered absurd and are now found admirable."

As to the man himself he looks on at the fight of which he is the cause with a smile, impassive as a builder of cathedrals. Barely did he feel the furtive discouragement which is felt by the

(1) Gaston Migeon.

(2) Francis Mair.

(3) Gaston Méry. 
modest, when standing on the heaped-up pile of his works, he may have been surprised to find himself no nearer to the sun. No sooner had he plucked away one bramble in his path, than ten fresh ones sprang up in its place. He continued his arduous task, as each one continues along his path in life. Nothing could quench the zeal which glowed in his heart, nothing will weaken his solitary effort, which, you may rest assured, will yet win the day. For, although timid, he is bold hungering after movement, he seizes upon it and embodies it. All his statues, or nearly all, are in motion, nod their heads, stretch out their arms, embrace. Their very repose is full of action. Whatever has been touched by the lion's claw is marked with an everlasting cicatrice. Genius has always this character of being individual. None resembles it, it is inspired by nobody, it is made of all things and of nothing. Having slaked his thirst at the fountain of Helicon, drunk with honey, he trembles and flies, pursued by the fauns, he staggers and falls and suffers and dies a thousand deaths until the day on which the glorious muse calls him saying, "Arise now, my brother and be the conqueror." Thus Rodin has fought and wept and suffered; thus will Rodin conquer.

And those who are most fitted with unrelenting contempt will admire, as much as they used to contemn them, these men who have hungered since their birth, these women whose tread is as light as that of young birds, these lovers aglow with passion and strength, rays of sun- 
light shouting athwart the icy mists, these old men who mingle their sorrowful plaints with the joyful songs of children, this stream of life with its boiling waves and will understand the ingenuous artist who has followed the steps of mankind as it wallied before him.

\section{LÉON RIOTOR.}

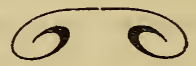




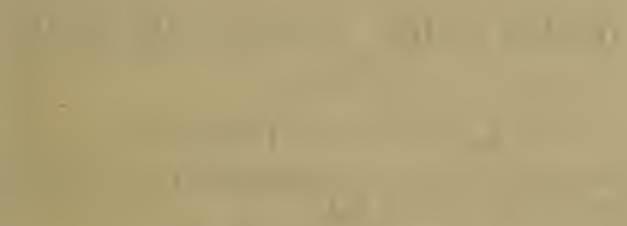

$+2$

$x^{2}$ 


\section{WORKS BY LÉON RIOTOR.}

\section{LEGENDARY POEMS.}

Le Pêcheur d'Anguilles, frontispiece by G. de Feure. Le Sage Empereur, 1 vol.

Fidélia, 1 vol., headpieces by Ed. Rocher.

Jeanne de Beaucais, title page by Frédéric Front.

\section{NOVELS.}

L'Ami inconnu, 1 vol.

Le Pressentiment, preface by Papus.

Le Pays de la Fortune, 1 vol., drawings by Léofanti.

La Vocation merocilleuse du célèbre cacique Piè. douche, 1 vol.

Les Raisons de Pascalin, 1 vol.

Agnès, 1 vol.

\section{PLAYS.}

L'Excuse, 1 act (with Felice Cavallotti).

Noce Bourgeoise, 1 act (with Ernest Raynaud).

Théatre d'Application, 1892.

\section{ESSAYS.}

Les Enfers Bouddhiques, 1 vol., with 12 separate plates, several drawings and 3 prefaces by Renan, Foucaux and Ledrain.

Le Parabolain.-Le Sceptique loyal, headpieces by Grasset.

Sur deux Nomarques des Lettres.

Des Bases classiques allemandes.

Essay sur Puvis de Chavannes, 1 vol., with a portrait, 2 plates in heliogravure and several drawings.

La Mode et le Mannequin, 1 vol., preface by Octave. Uzanne and several drawings.

Les Arts et les Lettres, 1st series, 1 vol. of 500 pages, preface by Gustave Geffroy, frontispiece by Puvis de Chavannes and several drawings:

PAIIS, - IMP, CKLALES SCHLABBER, 257, RUX SAINT-HONOṘ. 

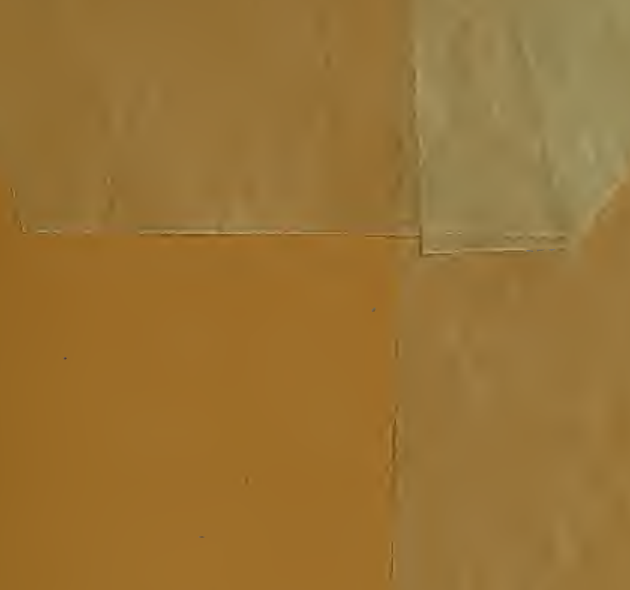

,
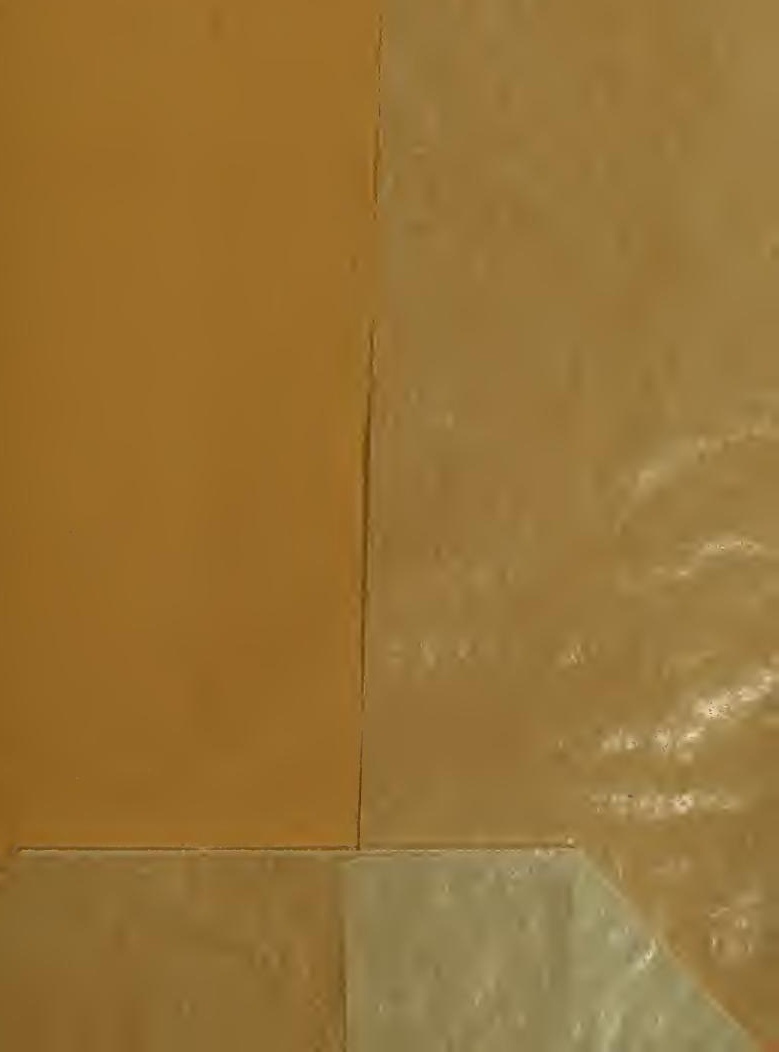
SMITHSONIAN INSTITUTION LIBRARIES

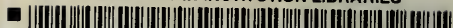

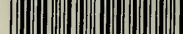

|||||||||||||||||||||||||||||||||||||||||||||||||||||||||||||||||||||||||||||||||||

39088011340890 